\title{
The effectiveness of playing Clay and Origami therapy to reduce anxiety pediatric patients hospitalized
}

\author{
Nur Sofiatun Kodiriya ${ }^{1 *}$; Zainal Munir ${ }^{2}$; Kholisotin $^{3}$; Ahmad Kholid Fauzi ${ }^{4}$; \\ Abdul Hamid Wahid ${ }^{5}$
}

1*); 2,3,4,5 Nurul Jadid University

\begin{tabular}{l}
\hline ARTICLE INFO \\
\hline Article history: \\
Received May 23, 2019 \\
Revised August 12, 2019 \\
Accepted August 24, 2019 \\
\hline
\end{tabular}

\author{
Keyword: \\ Hospitalization Anxiety \\ Play Therapy \\ Clay \\ Origami \\ *) corresponding author \\ Students of Health Faculty \\ Nurul Jadid University
}

Jl. PP Nurul Jadid, Dusun Tj. Lor,

Karanganyar, Kec. Paiton, Probolinggo, Jawa Timur 67291

Email: Nurshofiyatulq@gmail.com

DOI: https://doi.org/10.30604/jika.v4i2.200

\begin{abstract}
A B S T R A C T
Hospitality is a matter that requires the child to be hospitalized, which causes a lot of anxiety in children and for parents. Various feelings that often arise in children, namely anxiety, anger, sadness, fear and guilt. To reduce the effects of anxiety due to hospitalization experienced by children, we need a media that can express anxiety, one of which is play therapy. The purpose of this research was to determine the effect of clay and origami play therapy on reducing anxiety levels in hospitalization in preschool children (3-6 years) at Abdoer Rahem Situbondo Hospital. The design of this research uses Quasi Experiment Design, with the research design Time Series Design large sample of 90 preschool children (3-6 years), the sampling technique of this research uses purposive sampling, data collection is done using HARS observation sheets (hamilton anxiety Rating Scale) anxiety that is done directly to the respondent then measures the level of anxiety experienced by the respondent. This statistical test uses the Repeated Measures Anova test and the oneway anova test. The results of this research found there were differences in anxiety levels in preschoolers who were hospitalized before and after being given play therapy with a p-value of 0,000. While the comparative results of this research found that there was no difference in the level of anxiety reduction between the clay and origami play groups with a p-value of 0.977.
\end{abstract}

This is an open access article under the CC-BY-SA license.

\section{INTRODUCTION}

Hospitalization is a matter that requires children to be hospitalized which causes a lot of anxiety in children and for parents. Hospitalization is an effective way to cure a sick child. Because for children, hospitalization is an unpleasant experience (Hockenbery MJ, 2009). Various feelings that often arise in children undergoing 
hospitalization, namely anxiety, anger, sadness, fear and guilt (Wong DL. 2008).

The rate of hospitalization based on data from WHO in 2016 amounted to 530 million children hospitalized (63\%). Data on illness in children based on the disease as much as $166.7 \%$ (WHO, 2017). The morbidity rate of children in Indonesia is $15.26 \%$, the morbidity rate of children according to male gender is $15.39 \%$, girls is $15.13 \%$, while according to rural areas is $15.57 \%$, in urban areas $14.74 \%$ (KPP \& PA, 2015). While the morbidity rate of children, according to age, in the age group of $0-4$ years is $24.8 \%$, ages 5-9 years 20\%, 10-14 years 14\%, $15-19 \%$ 10\% (Statistics Indonesia, 2015).

Data on inpatient visits in East Java Province in 2015 has increased, based on data from the East Java Health Office reported number of visits of 442,059 people. The number of visits according to male sex $4.3 \%$, female $5.0 \%$ (Health Office of East Java, 2015). Based on the results of a preliminary research on December 24, 2018 in the Lotus Room of RSUD dr. Abdoer Rahem, Situbondo, found 116 children were hospitalized in November (Medical Records of Dr. Abdoer Rahem Regional Hospital, 2018).

The short-term impact of anxiety and fear experienced by hospitalized children if not treated immediately will make the child reject the actions of care and treatment given so that it affects the length of the day of care, aggravating the child's condition and can even cause death in children, while the longterm impact if not immediately dealt with will cause difficulties and poor reading skills, have language and cognitive development problems, decrease intellectual and social abilities and immune functions (Heri Saputro, 2017).

Children undergoing hospitalization need a medium to express their anxiety to reduce the effects of anxiety due to hospitalization experienced by children, one of which is play therapy (Supartini Y 2004).
Play is an activity carried out by children, based on their own desires to overcome difficulties, stresses and challenges encountered and communicate to achieve satisfaction in dealing with others (Wong 2009). Various kinds of play therapy that are in accordance with the principle of playing in hospitals that can be done to deal with anxiety due to hospitalization, one of which is clay and origami. Clay is a type of soft wax resembling clay, easily formed and there are many colors (Nor Ella Dayani, Lia Yulia Budiarti 2015). This clay game can be done on the child's bed, so it does not interfere in the process of restoring the health of children (Ngastiyah 2005).

Origami is an activity of folding paper so that it forms a form such as animal, flower, or transportation (Syaiful Y, Widati 2013). Playing origami teaches children to make their own toys, so that children feel a sense of satisfaction compared to toys that have been made or bought at toy stores (Hirai 2012).

The two games presented by researchers, researchers want to compare and combine two types of games which are games that require the movements of children's fingers, so that they can become an attractive form for physical skills that involve small muscles and the coordination of preschoolers' eyes and hands. It also helps train patience and improve concentration in children, learning to form this game requires hand coordination and concentration.

The purpose of this research is to analyze the effect of clay play therapy on reducing children's anxiety levels. Analyzing the effect of origami play therapy on reducing anxiety levels in children. Analyzing the effect of merging therapy (clay and origami) on the decrease in anxiety levels of children. Analyze the level of effectiveness of 3 play therapies.

\section{METHOD}

The design used in this research is the Quasi Experiment Design research design. This 
type of Quasi Experiment in this research takes the type of Time Series Design. This design is like a pretest posttest design.

The population in this research were all 116 pediatric patients who were hospitalized based on data obtained from the Medical Record in the Lotus Room of Abdoer Rahem Situbondo Regional Hospital. The number of samples that met the inclusion and exclusion criteria, to be treated in this research were 90 respondents, namely 30 respondents playing clay therapy, 30 respondents origami playing therapy, combined play therapy (clay and origami 30 ).

The sampling technique is done by Nonprobability Sampling, the method used is purposive sampling, where the sampling technique is done by selecting a sample among the population in accordance with what the researchers want, so that the sample can represent the characteristics of the population that was previously known, this research was conducted at January 25, 2019 February 22, 2019. Researchers chose children undergoing hospital treatment on the first and second days, then researchers observed data before and after being given play therapy for 20 minutes, in this research, observational data after playing therapy was observed in as many as 3 times i.e. 20 minutes the first day, 20 minutes the second day, 20 minutes the third day.

The tools and materials used in this research are clay, origami and clay and origami learning modules. The instrument used to measure the level of anxiety experienced by children is a structured observation sheet using the Hamilton Anxiety Rating Scale (HARS) consisting of 14 items, including: (a). Anxiety, (b) Tension (c) Fear (d) Sleep disturbance (e) Impaired intelligence (f) Depression (g) Somatic symptoms (h) Sensory symptoms (i) Cardiovascular symptoms (j) Respiratory symptoms (k) Symptoms gastrointestinal (l) Urogenital symptoms (m) Vegetative symptoms (n) Behavior during an interview.

\section{RESULTS AND DISCUSSION}

The results of the research will describe all data obtained at the research site carried out in the Lotus Room of Abdoer Rahem Situbondo Regional Hospital. In this case the role of respondents is children aged 3-6 years who have been hospitalized with a total of 90 respondents.

Table 1

Respondent Characteristics based on Gender, Age, length of treatment and level of anxiety before intervention

\begin{tabular}{lcccccc}
\hline \multirow{2}{*}{ Respondent Characteristics } & \multicolumn{2}{c}{ Clay } & \multicolumn{2}{c}{ Origami } & \multicolumn{2}{c}{ Clay\&Origami } \\
\cline { 2 - 7 } & f & $\%$ & f & $\%$ & f & $\%$ \\
\hline Gender & 13 & 43.3 & 14 & 46.6 & 11 & 36.7 \\
$\quad$ Male & 17 & 56.7 & 16 & 53.3 & 19 & 63.3 \\
$\quad$ Female & 11 & 36.7 & 10 & 33.3 & 11 & 36.7 \\
\hline Age & 10 & 33.3 & 8 & 26.7 & 7 & 23.3 \\
$\quad$ 3 year & 6 & 20 & 7 & 23.3 & 9 & 30 \\
$\quad$ 4 year & 3 & 10 & 5 & 16.7 & 3 & 10 \\
$\quad$ 5 year & & & & & & \\
$\quad$ year & 26 & 86.7 & 27 & 90 & 28 & 93.3 \\
$\quad$ Caring Period & 4 & 13.3 & 3 & 10 & 2 & 6.7 \\
$\quad$ Day 1 & Day 2 & & & & &
\end{tabular}




\begin{tabular}{lcccccc}
\hline Anxiety Level & 0 & 0 & 0 & 0 & 0 & 0 \\
Not Worried & 0 & 0 & 0 & 0 & 0 & 0 \\
Mild & 23 & 76.7 & 22 & 73.3 & 22 & 73.3 \\
Moderate & 7 & 23.3 & 8 & 26.7 & 8 & 26.7 \\
Severe & 0 & 0 & 0 & 0 & 0 & 0 \\
Very Severe & 0 &
\end{tabular}

Table 2

Homogeneity test of respondents' anxiety levels in the clay, origami and clay \& origami groups.

\begin{tabular}{lcccc}
\hline \multirow{2}{*}{ Variable } & $\mathbf{n}$ & \multicolumn{3}{c}{ Test of homogeneity of variances } \\
\cline { 3 - 5 } & & Df1 & Df2 & Sig \\
\hline Clay & 30 & 3 & 116 & 0.090 \\
\hline Origami & 30 & 3 & 116 & 0.085 \\
\hline Clay\&Origami & 30 & 3 & 116 & 0.327 \\
\hline
\end{tabular}

Table 3

Decreased level of anxiety after playing therapy

\begin{tabular}{|c|c|c|c|}
\hline Waktu Perlakuan & Mean & SD & p-value \\
\hline \multicolumn{4}{|l|}{ Play Clay Therapy } \\
\hline After day-1 & 23.10 & 0.360 & 0.000 \\
\hline After day -2 & 17.90 & 0.530 & 0.000 \\
\hline After day -3 & 15.03 & 0.435 & 0.000 \\
\hline \multicolumn{4}{|l|}{ Play Origami Therapy } \\
\hline After day -1 & 22.27 & 0.537 & 0.000 \\
\hline After day -2 & 17.87 & 0.540 & 0.000 \\
\hline After day -3 & 15.10 & 0.435 & 0.000 \\
\hline \multicolumn{4}{|l|}{ Pay clay and origami Therapy } \\
\hline After day -1 & 22.57 & 0.531 & 0.000 \\
\hline After day -2 & 17.97 & 0.533 & 0.000 \\
\hline After day -3 & 15.17 & 0.437 & 0.000 \\
\hline
\end{tabular}

The results of data analysis using the Repeated Measures Anova test obtained pvalue of 0,000 and a significant value of 0.05 . These results obtained a p-value of 0.000 $<0.05$ which means that Ho was rejected, so it can be concluded that there are differences in anxiety before and after being given clay play therapy in preschoolers at Abdoer Rahem Situbondo Regional Hospital.

The results of data analysis using the Repeated Measures Anova test obtained pvalue of 0,000 and a significant value of 0.05 . These results obtained a p-value of 0.000 $<0.05$ which means that Ho is rejected, so it can be concluded that there are differences in anxiety before and after being given origami play therapy in preschoolers at Abdoer Rahem Situbondo Regional Hospital.

The results of data analysis using the Repeated Measures Anova test obtained pvalue of 0,000 and a significant value of 0.05 . These results obtained a p-value of 0.000 $<0.05$ which means that Ho is rejected, so it can be concluded that there are differences in anxiety before and after being given Clay and Origami play therapy in preschoolers at Abdoer Rahem Situbondo Regional Hospital. 
Table 4

Comparison of decreased anxiety level after playing therapy

\begin{tabular}{|c|c|c|c|}
\hline Variable Independent & Ranks & SD & p-value \\
\hline Clay & 15.03 & 2.385 & \multirow{3}{*}{0.977} \\
\hline Origami & 15.10 & 2.383 & \\
\hline Clay \& Origami & 15.16 & 2.393 & \\
\hline
\end{tabular}

The results of data analysis using the Repeated Measures Anova test obtained pvalue of 0,000 and a significant value of 0.05 . These results obtained a $\mathrm{p}$-value of 0.000 $<0.05$ which means that Ho is rejected, so it can be concluded that there are differences in anxiety before and after given clay and origami play therapy in preschoolers at Abdoer Rahem Situbondo Regional Hospital.

The results of data analysis using the One Way Anova test obtained the above values can be seen that the average score in the clay playing group is 15.03 obtained the SD value 2,385 , origami 15.10 obtained the SD value 2,383 , clay \& origami 15.16 obtained the SD value 2,393 and $p$-value 0.977 so it can be concluded that $\mathrm{p}$-value> 0.05 , there is no difference in the effectiveness level of play therapy to the level of anxiety reduction in children who are hospitalized.

\section{Analysis of Respondents by Gender}

Based on the results of research conducted in January to February 2019 in the Lotus Room Abdoer Rahem Situbondo Regional Hospital, it was found that the majority of respondents in the clay group were female, 17 children $(56.7 \%)$, and the minority of male respondents were 13 children $(43.3 \%)$. In the origami group, the majority were female, 16 children $(53.3 \%)$, and the minority were 14 children $(46.6 \%)$. While in the clay \& origami group the majority of respondents were female, 19 children $(63.3 \%)$, and the minority of male respondents were 11 children $(36.7 \%)$.

This is in line with Mahat and Scoloveno's statement in the Apriliawati A thesis, 2011 that girls who undergo hospitalization will have higher levels of anxiety than boys. This is possibly because of the influence of the hormone estrogen which when interacting with serotonin will trigger anxiety (Apriliawati A, 2011). This is reinforced by the theory of Stuart, G. W., 2006 which states that girls are easier to experience anxiety than boys because the hormone estrogen in women is more than in boys (Stuart, G. W., 2006).

Researchers state that boys are easier to interact with researchers than girls who require longer time to interact and also boys tend to be more active and exploratory while girls are more sensitive.

\section{Analysis of Respondents by Age}

Based on the results of the research above, it can be seen that the age characteristics of the majority of respondents in the clay group are 3 years old $(11.7 \%)$, and the minority of respondents (6 years old) are 3 children $(10 \%)$. In the origami group the majority were 3 years old, 10 children $(33.3 \%)$, and the minority of respondents who were 6 years old were 5 children $(16.7 \%)$. Whereas in the clay \& origami group the majority of respondents were 3 years old namely 11 children $(36.7 \%)$, and the minority of respondents were 6 years old i.e. 3 children $(10 \%)$.

At preschool age, especially in children aged 3 years, children are more prone to accidents and injuries. Injuries suffered by children can include falls, aspirations and burns allow children to undergo treatment in hospital (Muscari ME, 2006). This is related to the child's immune system which will continue to develop along with increasing age of the child so that the younger the age of the child will be more at risk of hospitalization due to 
the defense of the child's immune system that is still developing so vulnerable to disease exposure (Sacharin, 1996).

Based on the results of anxiety measurements using the Hars (Hamilton Anxiety Rating Scale) observation sheet, it was found that 3year-old children had higher anxiety scores than 6-year-old children.

This is in line with the statement by Stuart and Laraia 2005 that younger children have mastery of immature egos and have not been able to solve problems according to reality, making it easier to experience anxiety than older children (Stuart, GW \& Sundeen, SJ, 2006). Another statement by Sacharin, 1996 is that the younger the child is, the more difficult it will be for the child to adjust to a new environment he knows, such as hospital experience (W. D. Hockenbery MJ, 2009).

\section{Analysis of Respondents Based on Length of} Stay

Based on the results of the research it can be seen that the characteristics of respondents based on the length of stay in the clay group, the origami group and the majority of the clay \& origami group were treated on the first day.

Based on the results of measuring anxiety using the Hars (Hamilton Anxiety Rating Scale) observation sheet it was found that children who were treated on the first day tend to have higher anxiety scores than children who have been treated for 2 days. In the thesis (Purwandari H, 2009) states that anxiety children who are hospitalized will be very visible on the first day, second and third entering the fourth day or fifth day the anxiety felt by children will begin to decrease.

Analysis of differences in the level of anxiety of the respondents before and after giving clay play therapy

This research clarifies the level of anxiety of children who are hospitalized using the Hars (Hamilton Anxiety Rating Scale) observation sheet. The results of statistical tests between the first 20 minutes, the second 20 minutes, the third 20 minutes found a decrease in effective anxiety levels in the third 20 minutes with a mean value of 15.03 with SD 0.435 , with a $\mathrm{P}$-value of 0.000 so that it can be concluded that $\mathrm{p}<0.05$ Ho is rejected and Ha accepted which means there is influence and there are significant differences between anxiety levels before and after given clay play therapy.

The success of play therapy in reducing anxiety of preschool children during hospitalization is not only influenced by the tools and types of games that are appropriate and in accordance with the stage of growth and development of children, may also be influenced by the type of color of the playdough itself. This can be seen from the majority of respondents who prefer and like the color green in making a particular shape made from playdough. The green color can provide psychological effects in overcoming emotional problems experienced by children such as when the child is stressed, anxious, emotional, and afraid during the child undergoing treatment in hospital, the green color is considered to have the power to heal and the ability to calm (Harini N., 2013) .

In connection with the concept of providing therapy which is 20 minutes for 3 days, the results of the analysis are obtained on the first 20 minutes of the day, the respondent still looks scared and there must be parents who accompany because the new respondent adapts to the researcher, on the first 20 minutes of the day, the researcher adapts, accompanies and teaches respondents to make and shape clay. On the 20th minute of the second day the respondent began to be very active in interacting with the researcher, the respondent was no longer accompanied by the parents, the researcher only accompanied and observed the client's response when, after being given clay play therapy. On the 20th minute the third day the respondents showed very cooperative, so the research results obtained play very effective therapy on the 20th minute the third day. 
Analysis of the difference in respondents' anxiety levels before and after being given origami play therapy

This research clarifies the level of anxiety of children who are hospitalized using the Hars (Hamilton Anxiety Rating Scale) observation sheet. Statistical test results between the first 20 minutes, the second 20 minutes, the third 20 minutes showed a decrease in the level of anxiety that is effective in the third 20 minutes with a mean value of 15.10 with SD 0.435 with a $\mathrm{P}$-value of 0.000 so that it can be concluded that $p<0.05$ Ho is rejected and $\mathrm{Ha}$ is accepted which means there is influence and there is a significant difference between before and after being given origami play therapy.

Origami is an activity of folding paper to form something, for example animal shapes, flowers, or means of transportation (Syaiful Y, Widati, 2013). Origami play therapy provides an opportunity for children to make various forms of paper folding and at this age, children will feel proud of something that has been produced.

This is consistent with the theory of the psychosocial development stage of preschoolers which suggests that preschoolers begin to develop their desires by exploring the surrounding environment. The child will also feel satisfied and proud of his ability to produce something as his achievement. Feelings of pride help children improve their role during the process of hospitalization so that feelings of loss of control due to restrictions on activities in children can be overcome / eliminated. If anxiety stresses in the form of loss of control can be overcome, then the level of anxiety in children can decrease (Supartini Y, 2004).

In connection with the concept of providing therapy, which is 20 minutes for 3 days, the results of the analysis are obtained on the first 20 minutes of the day, the respondent still looks scared and there must be parents who accompany because the new respondent adapts to the researcher, in the first 20 minutes of the day, the researcher adapts, accompanies and teaches respondents to make and shape origami. On the 20th minute of the second day the respondents began to be very active in interacting with researchers, respondents were no longer accompanied by parents, researchers only accompanied and observed client responses when given origami play therapy. On the 20th minute the third day the respondents showed very cooperative, so the research results obtained play very effective therapy on the 20th minute the third day.

Analysis of respondent's anxiety level before and after giving clay \& origami play therapy

This research clarifies the level of anxiety of children who are hospitalized using the Hars (Hamilton Anxiety Rating Scale) observation sheet. The results of statistical tests between the first 20 minutes, the second 20 minutes, the third 20 minutes found a decrease in effective anxiety levels in the third 20 minutes with a mean value of 15.17 with SD 0.437 with a P-value of 0.000 so that it can be concluded that $p<0.05$ Ho is rejected and $\mathrm{Ha}$ is accepted which means there is influence and there is a significant difference between anxiety levels before and after being given clay $\&$ origami play therapy.

Concept In this clay \& origami therapy dividing the time of 20 minutes into $2 \times 10$ minutes, the first 10 minutes are given clay play therapy while the second 10 minutes are given origami play therapy

When doing the clay \& origami play therapy process on the first and second day most of the children showed good responses such as children who seemed enthusiastic, happy and enjoyed the games provided by the researchers. In this research respondents experienced confusion and loss of focus due to getting 2 games that are not one unit, some respondents prefer playing clay and those who like playing origami.

In connection with the concept of providing therapy, which is 20 minutes for 3 days, the 
results of the analysis are obtained on the first 20 minutes of the day, the respondent still looks scared and there must be parents who accompany because the new respondent adapts to the researcher, in the first 20 minutes of the day, the researcher adapts, accompanies and teaches respondents to make and shape clay \& orgami. On the 20th minute of the second day the respondents began to be very active in interacting with researchers, respondents were no longer accompanied by parents, researchers only accompanied and observed client responses when given clay \& origami play therapy. On the 20th minute the third day the respondents showed very cooperative, so the research results obtained play very effective therapy on the 20th minute the third day.

\section{Analysis of the effectiveness level of 3 playgroups to reduce levels of anxiety in hospitalized children}

From the three interventions, it has been found that the three play therapies are very effective in reducing the anxiety level of hospitalized children. The results of data analysis using the One Way Anova test obtained an average in the Clay group 15.03, Origami 15.10, Clay \& Origami 15.16, when seen from the average of the three groups at a glance, there were differences, but could not conclude only from the average value but which It needs to be seen that the p-value obtained in this research is 0.977 , that the pvalue $>0.05$ so that it can be concluded that $\mathrm{Ho}$ is accepted and $\mathrm{Ha}$ is rejected, which means that the play therapy given to the 3 groups has no significant difference.

Clay and origami are games that sharpen the brain of children to form something such as animals, fruits, flowers, etc., as well as clay and origami materials, there are various kinds of colors that can cause a sense of interesting children to play and children can find out various colors. Besides clay and origami can develop children's motor functions, children are very easy to play so that children have no difficulty in forming and making them. When a child succeeds in making and shaping clay and origami, the child experiences satisfaction and gives pleasure and pride to the child where the child can make their own toys. Feelings of pleasure and pride can make children adapt to anxiety stressors during hospitalization. Feeling comfortable will stimulate the expenditure of endorphin hormones in the body. Increased endorphin hormones in the body will affect mood and can reduce anxiety. This hormone can also cause muscles to relax and increase the immune system. In addition to endorphin hormones the body will also release GABA and enkephalin, which can cause analgesia so that pain in children undergoing hospitalization can be reduced or lost (Halimatus \& Hardiani, 2014).

\section{CONCLUSIONS AND SUGGESTIONS}

Based on the results of the research it can be concluded that there is an effect of clay and origami play therapy on reducing anxiety levels in hospitalization of preschool children, when researchers combine the two games, the game still influences the reduction in anxiety levels of children. Comparison of the level of effectiveness in this play therapy There is no difference in the effect of clay and origami play therapy on reducing anxiety levels in the hospitalization of preschool children.

Suggestions for further researchers are expected this research can be used as a basis for further research that will examine different variables, so that it will get a more influential analysis to reduce anxiety in preschoolers. Suggestions for hospitals to implement play therapy that researchers do and provide play therapy according to the age of development. 


\section{REFERENCES}

Apriliawati, A. (2011), Pengaruh Biblioterapi terhadap tingkat kecemasan anak usia sekolah yang menjalani hospitalisasi di Rumah Sakit Islam Jakarta. Universitas Indonesia. https://doi.org/10.31004/obsesi.v1i2.21

Badan Pusat Statistik. (2015). Profil Kesehatan Ibu dan Anak. Badan Pusat Statistik. https://www.bps.go.id/publication/201 6/12/20/14646448c68db5af30735247/ profil-kesehatan-ibu-dan-anak2015.html

Dinkes Jawa Timur. (2015). Profil Kesehatan Provinsi Jawa Timur. www.depkes.go.id/resources/.../profil/ PROFIL...PROVINSI_2016/15 Jatim 2016.pdf

Sa`diah, R., Hardiani, R., \& Rondhianto, R. (2014). Pengaruh Terapi Bermain Origami terhadap Tingkat Kecemasan pada Anak Prasekolah dengan Hospitalisasi di Ruang Aster RSD dr. Soebandi Jember (The Effect of Origami Play Therapy toward Anxiety Level on Preschool Age Children Hospitalization in Aster's Room. Pustaka Kesehatan, 2(3), 530 536.

Retrieved from https://jurnal.unej.ac.id/index.php /JPK/article/view/2381

Harini N. (2013). Terapi warna untuk mengurangi kecemasan. Jurnal Ilmiah Psikologi Terapan Fakultas Psikologi Universitas Muhamadiyah Malang. Jurnal Ilmiah Psikologi Terapan, 1(2), 291-303.

ejournal.umm.ac.id/index.php/jipt/artic le/view/1584

Heri Saputro, I. F. (2017). Anak Sakit Wajib Bermain di Rumah Sakit. Penerapan Terapi Bermain Anak Sakit; Proses, Manfaat dan Pelaksanaannya (Eva Agustina Yalestyarini, Ed.). Ponorogo: Forum Ilmiah Kesehatan (FORIKES). ners.stikesstrada.ac.id/wpcontent/uploads/.../Buku-Ajar-TerapiBermain-Anak.pdf

Hirai, M. (2012). Fun Origami. Jakarta: Kawan pustaka. https://books.google.co.id/books?isbn $=9797575217$

Hockenbery MJ, W. D. (2009). Wong's esensial pediatric nursing (8th ed.). St Louis: Mosby Elsevier. https://evolve.elsevier.com/cs/product/ 9780323077811? role $=$ student

KPP\&PA. (2015). Profil anak indonesia 2015 (pp. 35-36). Kementerian Pemberdayaan Perempuan dan Perlindungan Anak (KPP\&PA). https://www.kemenpppa.go.id/lib/uplo ads/slider/c7c3e-profil-anak-indonesia2015.pdf

Muscari ME. 2006, Panduan belajar keperawatan pediatrik (3rd ed.). Jakarta: EGC.

Ngastiyah. (2005). Perawatan Anak Sakit. 2nd ed. Jakarta: EGC.

Nor Ella Dayani, Lia Yulia Budiarti, Dhian Ririn Lestari. (2015). Terapi Bermain Clay Terhadap Kecemasan Pada Anak Usia Prasekolah (3-6 Tahun) Yang Menjalani Hospitalisasi Di Rsud Banjarbaru. Dunia Keperawatan : Jurnal Keperawatan dan Kesehatan, $3(2)$.

https://ppjp.ulm.ac.id/journal/index.ph $\mathrm{p} / \mathrm{JDK} /$ article/view/592

Rekam Medik RSUD dr. Abdoer Rahem. (2018). reka.

Sacharin, R. M. (1996). Prinsip Perawatan Pediatrik (2nd ed.). Jakarta: EGC. repository.usu.ac.id/bitstream/handle/1 23456789/17139/Reference.pdf?seque nce.

Supartini Y. (2004). "Buku Ajar Konsep Dasar Keperawatan Anak.” In Jakarta: 
EGC.

https://books.google.co.id/books?id=IEgphlP8E8C\&pg=PR14\&dq=Buku+ Ajar+Konsep+Dasar+Keperawatan+A nak\&hl=id\&sa=X\&ved=0ahUKEwib1 NmXy8LiAhVKLK0KHa07A1QQ6A EILTAA\#v=onepage\&q=Buku\%20Aja r\%20Konsep\%20Dasar\%20Keperawat an\%20Anak \&f=false

Stuart, G. W. (2006). Buku Saku Keperawatan Jiwa. 5th ed. Jakarta: EGC.

lib.ui.ac.id/file?file $=$ pdf/metadata20100252.pdf

Stuart, G.W. \& Sundeen, S.J. (2006). Buku Saku Keperawatan Jiwa. 3rd ed. Jakarta: $\quad$ EGC. $\quad \underline{\text { Retrieve }}$ fromlib.ui.ac.id/file?file=pdf/metadata20100252.pdf

Syaiful Y, Widati, Rahmawati DW. (2013). "Pengaruh Terapi Bermain: Origami Terhadap Perkembangan Motorik Halus Dan Kognitif Anak Usia Prasekolah (4-6 Tahun)." Journals of Ners Community 3: 16-29. https://journal.unigres.ac.id/index.php/ JNC/article/view/107

WHO. (2017). World Health Organization. https://www.who.int/gho/publications/ world_health_statistics/2017/en/

Wong DL. (2008). Buku Ajar Keperawatan Pediatric. 1st ed. Jakarta: EGC. https://books.google.co.id/books?id=H HjThPtweDsC\&dq=Wong+L.+2008.+ Buku+Ajar+Keperawatan+Pediatric.\&

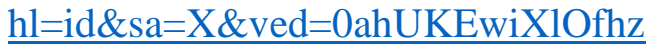
MLiAhVRMawKHTqJBvcQ6AEILT $\underline{\mathrm{AA}}$

Wong, D. L. (2009). Buku Ajar Keperawatan Pediatrik. Vol 1. Jakarta: EGC. https://books.google.co.id/books?id=H HjThPtweDsC\&dq=Wong+L.+2008.+ Buku+Ajar+Keperawatan+Pediatric.\& hl=id\&sa=X\&ved=0ahUKEwiXlOfhz MLiAhVRMawKHTqJBvcQ6AEILT $\underline{\mathrm{AA}}$ 